\title{
The Meaning of Work among Millennial: A Phenomenological Study
}

\author{
Peranginangin Prasasti ${ }^{1 *}$ and Saragih Denni Boy ${ }^{2}$ \\ ${ }^{1}$ Department of Management, School of Business and Economics, UKRIDA, \\ Jl. Tanjung Duren Raya No. 4 Grogol Petamburan, Jakarta 11450, Indonesia \\ ${ }^{2}$ Center of Character Development, School of Medicine, UKRIDA, \\ Jl. Tanjung Duren Raya No. 4 Grogol Petamburan, Jakarta 11450, Indonesia
}

\begin{abstract}
Some studies show that spirituality and productivity are closely related to the workplace. Three main components in the spirituality of work are the meaning of work, the relationship with fellow-worker and the cultural values of the organization. This phenomenological study focuses on the meaning of work among millennials. As an exploratory study, using phenomenological analysis, it found that millennials give meaning to work based on three important factors, namely, its individual meaningfulness, the fairness of treatment, and the balance between reward and level of work-demand. Millennial does not make income and personal development as their primary considerations but rather a more spiritual side of work visà-vis meaning and support one finds in the office. This exploratory study suggests some important ramifications for dealing with millennials in the work place.
\end{abstract}

Keywords: Balance, fairness, meaning of work, individual meaningfulness, spirituality of work

\section{Introduction}

Viktor Frank [in 1], in his famous book, says, “Man's main concern is not to gain pleasure or to avoid pain but rather to see a meaning in his life". Searching for meaning is part of work spirituality and can be understood as a process of how one finds meaning in a working environment [2]. Aspects of the work spirituality include the meaning of work, the impact on society and the significance one contributes to the company.

Milliman, Czaplewski, and Ferguson [in 3] found that one of the most important indicators of work spirituality is the meaningfulness of the work. This, in turn, will shape work behavior and productivity, that in the long run, contribute to the increase in the turn over. The meaning of work helps to shape a healthy relationship with internal life, mantain integrity, a sense of transcendance, connectedness with others, and/or the search for meaning and purpose in life and involve a worker in an engaging community [4].

The study of the meaning of work among millennial become more important as the demographical bonus of Indonesia place them as the main work force between the years of 2020 to 2030 [5]. The influence of millennials will be felt in all areas of life, including

\footnotetext{
* Corresponding author: prasasti.peranginangin@ukrida.ac.id
} 
social, politics, cultural, and economy. At present, they are $50.36 \%$ of the working force. This means they will be more and more dominant in shaping the dynamic of working place. New online businesses in Indonesia such as Gojek, Bukalapak, Tokopedia, or ruangguru.com, show that their presence is more and more strongly felt. Tulgan, in his study, observes that:

[The millennial] are the most high-maintenance workforce in the history of the world'. Millennials want to customize their very minds, bodies, and spirits. Millennial customize their minds by customizing their information environment on the Internet. They voraciously pursue an ever-increasing array of mind food-images, sounds, experiences, texts - in an ever-increasing range of media and formats, from an ever increasing number of sources, for an ever-increasing number of purposes (education, skills training, self-help, health, entertainment, news, household matters, consumer interests, life planning, death planning, spirituality, and so on [6].

Additionally, as the study of Kowske, Rasch, and Wiley shows, millennial demand a higher degree of security, acknowledgement, career success, and work satisfaction compared to previous generations [7], on the other hand, there are studies that suggest they might become the most productive working force if one knows how to manage them [6]. As such this study explores how they find meaning in the work place and how they perceive the impact they make to society contribute to the spirituality and the meaning of work.

\subsection{Research questions}

Specifically, this research will explore the following questions:

i. How the millennial give meaning to work?

ii. How they react to the social climate of office in relation to its meaning?

iii. What are the criteria they use to give meaning to work?

\subsection{Purpose of the study}

i. To explore the meaning of work among millennial

ii. To explore how they react to the social climate of the work

iii. To understand the criteria they use in giving meaning to their work

\subsection{Conceptual models}

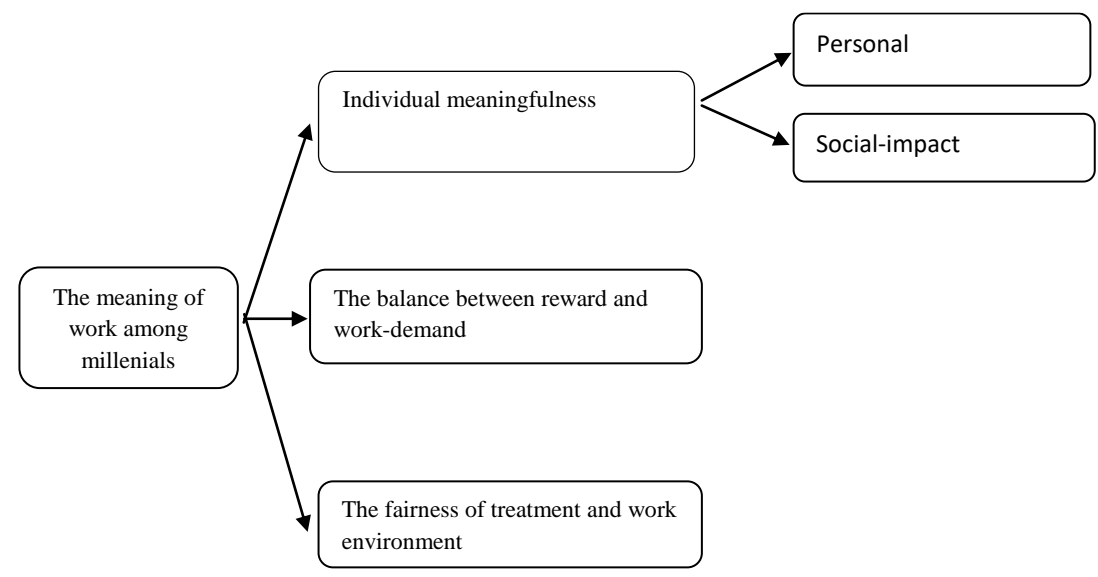

Fig. 1. Conceptual models of meaning of work 


\section{Research methods}

This is qualitative research with the approach of inductive phenomenological. There are four participants in the interview, and their data are coded thematically and classified according to Yogatama and Widyarini work [3].

The results of the interview are analysed according to the following steps: (i) Enlisting all relevant expressions found in the interview verbatim. (ii) Analysing and dividing each expression of experience according to its importance for clarifying the phenomenon. (iii) Clustering phenomena, according to themes folowing the analyses of participant's responses. Also, (iv) Narrating the phenomena in relation to theories and thinking of previous researches to discuss relevant insights into the phenomenon.

The following are the characteristics of the participants:

Participant 1: female, age $25 \mathrm{yr}$ old, $3 \mathrm{yr}$ in the company, work in manufactoring Participant 2: female, age $25 \mathrm{yr}$ old, $2 \mathrm{yr}$ in the company, work in an educational institution Participant 3: male, age $25 \mathrm{yr}$ old, 1 yr in the company, work in a Start-up company Participant 4: male, age 29 yr old, 1 yr in the company, work in a Fintech company

\section{Findings and conclusion}

Following our working theory, the meaning of work among millennials is divided into three important phenomena. First, individual meaningfulness can be seen from its opportunity for personal actualisation, and social impact one makes to and through the office. Second, the perceived fairness and equal treatment that millennial felt in the office. Millennial found the work is meaningful if one is free for self-expression, see fairness between job description and its reward, and the appreciation for role and contribution. In this regard, there are important differences between millennial and the previous generation (Gen X or Babyboomers) in relation to what one can do through the work. And finally, they find meaning if they feel justice in the demand and the benefit of the work. Salary is not the utmost factor in their decision but rather the overall benefit from the office and what kind of treatment they receive as an individual.

\subsection{Individual meaningfulness}

Participant 1

My talent cannot be used fully in my present position. I felt that the job-description and the reality of the work are in contradiction. The spirit in work is not there. I might leave this job because of the stress, and I see that many times, I was not feeling well because of the pressure. If the work is similar to the job-description, I might love to do this kind of job. But presently it demands me to do both finance and tax, which I feel too heavy. The load is only for fulfilling company turnover and financial gain. I don't see the good social relationships in the work place.

Participant 3

What I like about my present work is the opportunity to use my talent and gift to explore new things and to solve problems, especially if I was given the freedom to do that without the help of my supervisor. The working climate is very conducive to learn new things, and I like the opportunity to exchange ideas and to build a network with other and to criticise each other with a positive attitude openly. I also like our office program to reach out to the community. We support those who have potential but lack of financial resources to study in university. I also like it when we can share our knowledge with society in a way that simplifies life and to improve conventional ways of doing things. 


\section{Participant 4}

I find my work meaningful because I can contribute more to the company. If my idea is implemented, I see that I contribute more. The company is a new one, and the management in simpler, so I can work cross-departments. Personally, it helps to improve my communication skills. In a big company, people will only interact with one division. I can interact with people from IT and discuss our product. I also like the fact that our CEO routinely invites us to discuss issues. Additionally, because our company helps people who still lack access to the banking system, I found it really menaingful when our work helps them in an important way. We help such people to send money for business or for family.

Participants see meaningfulness in the workplace in two indicators. First, they find it meaningful when they can develop themselves and actualise their potential through the work. They found life is meaningful when their ideas and aspiration can be applied in the office and contribute to the advancement of the company as such a Start-up Company is an ideal working place for them. In this environment, they see it is meaningful to contribute to the significant development of the company. They find more freedom because it is not bureaucratic and ample room for creativity and new ideas. On the other hand, established companies tend to be more bureaucratic with rigid systems and values or upper management that form some kind of status-quo. One participant sees that working in such a company is less meaningful and thinking that two years is enough to gain experience and to explore new jobs with more meaning and freedom.

Second, participants find it meaningful when their work can contribute to society. Participant 1 see the work is not meaningful because the company only focus on financial gain. There is no clear connection between what one does in the company with the contribution to the society, and because of this, there is no spiritual dimension to work and only routine work that one needs to survive to maintain financial income, but the work itself is not for long term purpose.

Third, as can be seen in participant 3 and participant 4, they find satisfaction and meaningful job when what they do in the office can contribute to society. The work of creativity and innovation in the office when it is related to the need of society make the work meaningful and spiritual. The impact gives spirit to work done in the office and provides them with enthusiasm to find a better way of doing things.

\subsection{Fair treatment}

\section{Participant 1}

Sometime my boss asks me to do impossible things, that when asking to do something demanded it must be done right away. In my company, they demand us to do many things. Like me, I have an engineering background, but the company asks me to do finance. I do not find this meaningful.

Participant 2

In most of my job, my class is assigned in the morning with a team of lecturer. I find it is less satisfying because they don not ask me or discuss the job with me first. They just send the work to do in the email. But because I am considered as a junior lecturer, I find less freedom to express my opinion. In fact, I am the youngest, and I find no freedom to tell my opinion.

\section{Participant 3}

In the communication in my office, I feel so free that there is no more bos or underling. Every employee can express their opinion, as long as we can find ways to do our job more effectively and efficiently. Even we are free to have different opinions with the $C E O$, and if you make a mistake, you will be helped and not directly punished. And I can see that this is applied to all positions. 


\section{Participant 4}

Our value is openness. I see that the main company asset is people. We are free to express our opinion. Every two weeks the CEO comes down and opens communication with us. The goal of the company is very clear to me, so although my role is relatively small, but I can see that it is important for the company to thrive. Our work system is fleksible. It is according to responsibility. We have a flexible working schedule, and everybody can find their convenient as long as the job is done.

The participants' responses confirm the theory that millennial have a high demand for the working environment and require fair treatment for finding meaning in work. participant 1 and participant 2 plan to quit the job on two reasons namely because they find the job meaningless, i.e. they cannot develop their potential, and because they find that fair treatment is lacking. Participant 1 explains that demanding one to do something outside the passion and field of study is not reasonable. It is something that the company should not force its employees to do unless the employee accepts the responsibility based on consenting willingness. Participant 2 sees that it is unfair to enforce a job to an employee without discussion and personal agreement, i.e., based only on working contract. She demands that each job must be accepted willingly and provide a space for one to express self-actualisation.

On the other hand, participant 3 and participant 4 see meaning in their work because of the openness and freedom to express their opinion are graciously accommodated in the office. They see that it is fair and just that their creative contribution is appreciated as an important input to the development of the company. They like the free climate of the office where they can see themselves as free individuals and are not forced to make the demand for the work. To see one as an important part of the company is also enforced by direct communication with the CEO. The opportunity to give input and to ask explanations from the CEO give meaning to their personal existence in the work place. Start-up companies are among the best place that makes possible this working climate. The participants confirm that millennials are at home in the new office environment where open communication and direct interaction are the cultures of interaction. On the other hand, limited and bureaucratic communication are some of the barriers for them to find meaning in work.

\subsection{Balance between benefit and work-demand}

\section{Participant 1}

I see that double demand does not balance to the benefit. I think to get better benefits from work and to further my career path. The place is not in the present company.

Participant 2

Actually, this institution provides insurance and got benefits programs. But this is not the only thing that I am looking for.

Participant 3

Actually, the benefit that I receive from the present company is less than the responsibility I carry out. But because I see that the working environment is conducive, I will go with this company for some time. Surely there is a correlation between benefit and work-demand, but this is not so important to me. The meaning and freedom here are more important.

Participant 4

Outside normal company benefits, I also get personal benefits like I can learn new IT skills and up to date with the newest tech that I can apply to our product. Anyway, the salary is quite competitive compared to others, and I see that usually in Start-up they pay you quite well.

Participants confirm that for millennial salary while it is important but not the most important. They see that if their work can provide a balance scale between the benefit and meaningful side of the work, they will see that the work is worth it. Among factors that 
contribute to balance benefit, consideration is self-development, clear job-description, freedom and pressure, and working climate.

Participant 3 and participant 4 see that more meaning can be found in the Start-up Company because there is a balance between work demand to freedom and opportunity that they get. Because they enjoy the work, they can have time to enjoy social time, such as spending time with a friend in a cafe, doing social media, traveling, and up to date with the new tech.

On the other hand, participant 1 and participant 2 admit that their salary is quite good, and they quite satisfied with the amount. But the balance between work demand and the spiritual side of the work is not favourable. As such, they cannot see that the balance provides them with a meaningful life and work in the company. They see that they are not in one spirit with the company, and the work itself is more of kin to survival demand.

The participants confirm that for millennial balance in the work place is an important requirement for a meaningful job. They see that a good job is not so much one with a high salary but one with a good balance of benefit with freedom, flexibility, and room for expressing creativity. They will try to stay away or quit from the company with a rigid environment and bureaucratic style. Sonja said the present data indicated that corporations give more feedback than smaller, less hierarchical and bureaucratic organizations [8]. People with a job orientation focus on the material benefits of their work to the relative exclusion of other kinds of meaning and fulfillment [9]. Also, at least, emerging technology as a part of millennial ways should be recognized and responded as workplace motivation $[10,11]$. Therefore, the meaning of work among millennials is closely related to the personal view that the job helps them for self-actualisation, to be creative, and to have freedom. Especially important for a meaningful job is the fact that they can contribute to society through the work done in the company.

\section{Conclusion}

The study shows that millennials find meaning when they are involved in the decision making that is important for the company, i.e., that they are a matter for the development of the company. For a new generation of millennial workers, the benefit is not everything. They see that it is meaningful that they are asked their agreement or involved in the discussion for the tasks demanded from them. They seek the balance between benefit and personal development and job meaningfulness.

They like access to the top leaders in the company and see that limited communication makes the work lack meaning. They want to understand the agenda of the company and feel meaningful to be able to contribute something to that purpose. They see that work must have an element of joy, fun, and flexibility that help them balance the pressure with meaning. New companies such as Start-up company is the natural environment for millennial to find meaning and balance in the workplace. 


\section{References}

1. B.D. Rosso, K.H. Dekas, A. Wrzesniewski, Res. Organ. Behav., 30:91-127(2010). https://www.sciencedirect.com/science/article/pii/S0191308510000067

2. M. Scott, P.M. The Road Less Traveled : A New Psychology Of Love, Traditional Values And Spiritual Growth (25th Anniversary Edittion ed.). New York: Touchstone (2014). https://books.google.co.id/books?id=KNyvQxE466kC\&dq

3. L.A.M. Yogatama, N. Widyarini, J. Psikol., 42,1:1-14(2015). [in Bahasa Indonesia]. https://journal.ugm.ac.id/jpsi/article/view/6939

4. J.R. Tombaugh, C. Mayfield, R. Durand, Int. J. Organ. Anal., 19,2:146-170(2011). https://doi.org/10.1108/19348831111135083

5. Kemenppa, Profil Generasi Milenial Indonesia [Profile of Indonesian Millennial Generation]. (Statistik Gender Tematik ed.). Jakarta: Kementerian Pemberdayaan Perempuan dan Perlindungan Anak (2018). [Online]. [in Bahasa Indonesia]. https://www.kemenpppa.go.id/index.php/page/read/38/2049/profil-generasi-milenialindonesia-2018

6. B. Tulgan. Not Everyone Gets A Trophy: How To Manage The Millenials (Revised and Updated Edition ed.). Hoboken: John Wiley \& Sons (2016).

https://books.google.co.id/books?id=cwVdCgAAQBAJ\&dq

7. B.J. Kowske, R. Rasch, J. Wiley, J. Bus. Psychol., 25,2:265-279(2010). https://link.springer.com/article/10.1007/s10869-010-9171-8

8. S. Hannus. Traits of the millennial generation: Motivation and leadership. [Corporate Communication Master's Thesis]. Aalto: Department of Communication Aalto University School of Business (2016). http://epub.lib.aalto.fi/en/ethesis/pdf/14662/hse_ethesis_14662.pdf

9. B.D. Rosso, K.H. Dekas, A. Wrzesniewski, Res. Organ. Behav., 30:91-127(2010). https://doi.org/10.1016/j.riob.2011.10.001

10. A. Murray, The Australian Library Journal, 60,1:54-65(2011). https://www.tandfonline.com/doi/abs/10.1080/00049670.2011.10722556

11. R. Calk, A. Patrick, The Journal of Business Inquiry, 16,2:131-139(2017). http://161.28.100.113/index.php/jbi/article/view/81 